ppi $201502 Z U 4645$

Esta publicación científica en formato digital es continuidad de la revista impresa ISSN-Versión Impresa 0798-1406 / ISSN-Versión on line 2542-3185Depósito legal pp $197402 Z$ U34

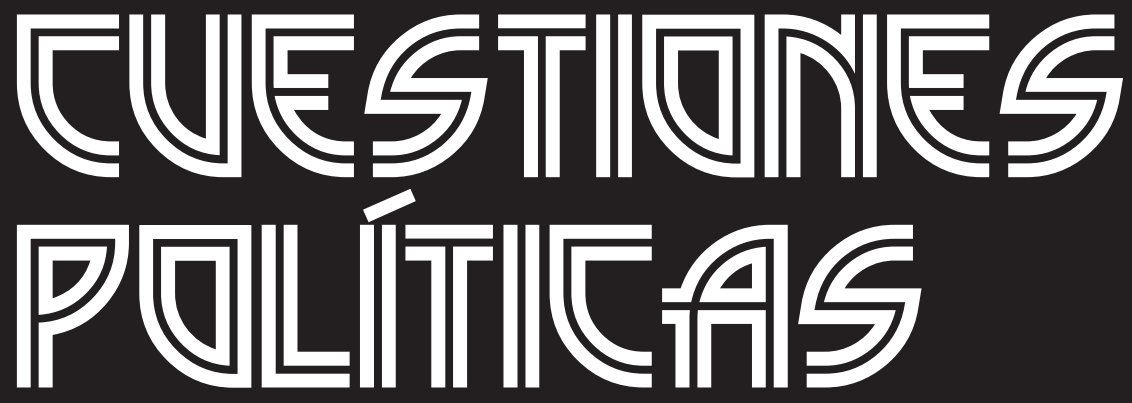

Instituto de Estudios Políticos y Derecho Público "Dr. Humberto J. La Roche" de la Facultad de Ciencias Jurídicas y Políticas de la Universidad del Zulia Maracaibo, Venezuela
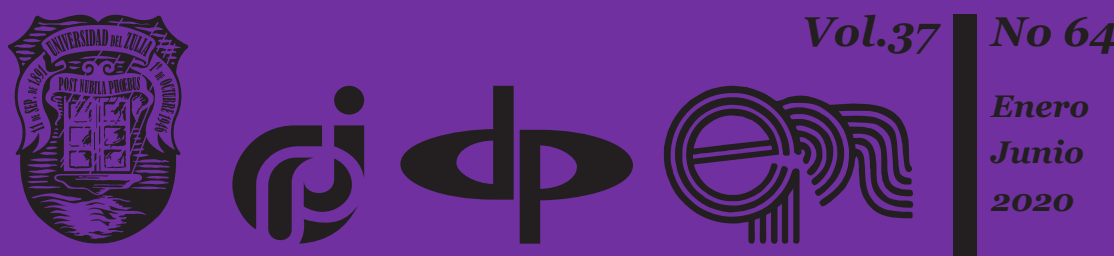


\title{
Provision of Escrow Services at the Absence of an Agreement: The Assessment for Compliance with the Russian Law
}

\author{
Liudmila Yu. Vasilevskaya * \\ Marina A. Rozhkova **
}

\begin{abstract}
Based on an analysis of the norms of the Civil Code of the Russian Federation, the authors studied the legal basis for the provision of a range of services by the online classified in the digital environment. Additionally, the authors studied the structure of relations arising between the buyer, seller, online classified, delivery service, and the bank. The article substantiates that there is a conditional escrow of property in the framework of the considered relations, but the fact of concluding an agreement creating an appropriate legal basis for such an escrow is not observed. The study results identify several civil law agreements, needed for the goods delivery services offered by online classifieds. The authors concluded that the relationship system built by the online classified with sellers, buyers, a delivery service, and a bank and providing for the reservation of the buyer's money excludes the conclusion of an escrow
\end{abstract} agreement.

Keywords: online classified; escrow; escrow agent; nominal account; electronic services.

* Doctor of Law, Kutafin Moscow State Law University, 9 Sadovaya-Kudrunskaya St., Moscow, 125993, Russia; Research and Consulting Council of the Supreme Court of the Russian Federation, 15 Povarskaya St., Moscow, 12126o, Russia; Expert Council on Ownership of the State Duma Committee on Economic Policy, Industry, Innovative Development, and Entrepreneurship, 1 Okhotny Ryad St., Moscow, 103265, Russia. Email: liudmila.yu.vasilevskaya@yandex.ru.

** Doctor of Law, Russian Academy of Sciences, 14 Leninsky prospekt, Moscow, 119991, Russia; Institute of Legislation and Comparative Law under the Government of the Russian Federation, 34 B. Cheremushkinskaya St., Moscow, 117218, Russia; Immanuel Kant Baltic Federal University, 14 A. Nevskogo St., Kaliningrad, 236016, Russia; Expert Council under the Committee on Information Policy of the State Duma, information technology and communications, 1 Okhotny Ryad St., Moscow, 103265, Russia. Email: marina.a.rozhkova@yandex.ru. 


\section{Prestación de Servicios de Custodia en Ausencia de un Acuerdo: la Evaluación del Cumplimiento de la Ley Rusa}

\section{Resumen}

Sobre la base de un análisis de las normas del Código Civil de la Federación de Rusia, los autores estudiaron la base legal para la prestación de una gama de servicios por parte de los clasificados en línea en el entorno digital. Además, los autores estudiaron la estructura de las relaciones que surgen entre el comprador, el vendedor, los clasificados en línea, el servicio de entrega y el banco. El artículo confirma que existe una custodia condicional de la propiedad en el marco de las relaciones consideradas, pero no se observa el hecho de concluir un acuerdo que cree una base legal adecuada para dicha custodia. Los resultados del estudio identifican varios acuerdos de derecho civil, necesarios para los servicios de entrega de bienes ofrecidos por los clasificados en línea. Los autores llegaron a la conclusión de que el sistema de relación creado por los clasificados en línea con vendedores, compradores, un servicio de entrega y un banco y que prevé la reserva del dinero del comprador excluye la celebración de un acuerdo de depósito en garantía.

Palabras clave: clasificados en línea; custodia; agente de custodia; cuenta nomina; servicios electrónicos.

\section{Introduction}

Currently, there is a rapid increase in the volume and variety of services provided and received in electronic form (hereinafter referred to as the electronic services). Where the indisputable positive perception by the society of this circumstance, lawyers cannot help but notice that insufficiently clear understanding by consumers of the properties of certain digital technologies, coupled with low legal literacy, often leads to the fact that citizens' rights when receiving electronic services are violated, and the protection of their rights is difficult. The latter circumstance often becomes the result not so much of the novelty and unsettledness of relations arising in the digital sphere, as of confusion or insufficient conceptual elaboration of national legislation.

The situation worsens, even more, when the unclear participants of the civil turnover begin to use the vagueness or whiteness of the legal provisions, using legal constructions that, when they appear to comply with the norms of the current legislation, do not meet the requirements of the law. This, in the authors' opinion, is unacceptable. Legislative innovations should be carefully 
worked out to exclude situations where the interested person cannot receive proper legal protection of their violated rights. Additionally, the emerging law enforcement practice should undergo an expert assessment and verification, which will allow for identifying miscalculations and shortcomings in the working law principles.

The complexity of the legal regulation of relations regarding the provision of electronic services is also largely connected to the fact that this concept covers a very wide range of diverse services. The qualifying features of electronic services, as follows from the Explanatory notes on the EU VAT changes to the place of supply of telecommunications, broadcasting and electronic services that enter into force in 2015 (clause 2.4.3.1), are that they are provided (1) via the Internet and (2), as a rule, in automatic mode (without human intervention). Therefore, most of the services provided to consumers by Internet platforms, clearly fall into the category of "electronic".

The provision of electronic services also applies to the activities of online-classifieds. The term "classified" denotes websites where individuals and companies place ads in various categories and relevant sections ("real estate", "cars", "work", "services", etc.). Online classifieds are divided into two main types: vertical, that is, working in one area (for example, in real estate or car sales), and horizontal, that is, multifunctional. Moreover, the work of a classified website requires the creation of an Internet platform, where registered users themselves fill the content to the platform's database: users indicate information about themselves when registering on the website (creating a profile), and information related directly to the ads - upon subsequent placement of these ads themselves in the relevant sections of the site.

The task of a classified website is to facilitate the dissemination of ads by bringing information about them to the maximum number of interested parties and to ensure the contact with those who placed the ad (Rozhkova, 2019). As an "advertisement board", online classifieds are designed to connect people interested in goods, services, vacancies, and other offers. Moreover, online classified often perform their main purpose, which is to connect the seller and the buyer, acting as an intermediary, free of charge. Because of this, an unlimited circle of persons is free to use the service of the classified website, receiving information about goods, services, vacancies from the catalog of announcements, and about registered users from their public profiles. In turn, any registered user of the service acquires a free opportunity to place their advertisement or resume in the corresponding thematic catalog; exchange instant messages with other registered users and the administration of the classified website.

At the same time, additional features provided by a classified website to a registered user, as a rule, imply that users pay for them. These can be a promotion or highlighting ads, advertisement ads, subscriptions, special 
Liudmila Yu. Vasilevskaya y Marina A. Rozhkova

Provision of Escrow Services at the Absence of an Agreement: the Assessment for Compliance 114 with the Russian Law

services for business, etc. That is, the source of income for an online classified is precisely the provision of additional services, the vast majority of which, of course, are electronic.

Such services, which are extremely interesting from a research point of view, include the Avito Delivery service package, offered at the Avito classified website, hosted by the 'avito.ru' domain name. This range of services is available only to users registered on the Avito classified website and is permissible only if it is specifically indicated in the announcement of the sale of goods (the possibility of provisioning Avito Delivery services is limited to the website concerning certain groups of goods or is blocked by the user concerning all or specific goods sold by that user).

A study of the legal characteristics and nature of the specified range of services should be preceded by an indication that the Avito classified site is a product of the well-known Swedish company Avito Holding AB. Therewith the relations arising regarding a classified website and the services it provides, in virtue by the clauses 1 and 2 of Article 1212 of the Civil Code of the Russian Federation (hereinafter referred to as the RF CC), are subject to the Russian law, which is attributable to that the activity of an online classified website is aimed at the Russian consumer and the territory of the Russian Federation, the domain 'avito.ru' used by the classified website is part of the Russian domain zone, all information on the website is posted in Russian, the online classified activity is provided with the option to make settlements in rubles and using payment tools available to Russian consumers, etc (Civil Code of the Russian Federation, 1994: article 1212, clauses 1 and 2).

Despite the seeming simplicity of the actions performed by users who have chosen the Avito Delivery package of services, from a legal point of view, the system of emerging relationships between its participants - seller, buyer, online classified, delivery service, and bank - seem very ambiguous and somewhat confusing. In the authors' opinion, even though it would seem that the authors are talking exclusively about the delivery of the ordered goods, here the escrow agreement design is used in the way it was introduced in the RF CC by the Federal Law (Federal Law of July 26, 2017), which is one of the variants of the agreement that has become widespread in the countries of the Anglo-American legal system under the name "escrow agreement", and which is Treuhandkonto in German legal system (Vasilevskaya, 2016).

A study of the indicated complex of services must be preceded by a brief overview of the content and features of several agreements, including escrow agreement (Civil Code of the Russian Federation, 1994: chapter 47.1), nominal account agreement (Civil Code of the Russian Federation, 1994: chapter 45, paragraph 2) and escrow account agreement (Civil Code of the Russian Federation, 1994: chapter 45, paragraph 3). 


\section{Theoretical Basis: Escrow Agreement (Hereinafter Referred to as the EA)}

Russian law stipulates that, under the EA, the depositor undertakes to transfer property for the escrow agent to be deposited to fulfill the depositor's obligation to transfer it to another person in whose favor the deposit is made (to the beneficiary), and the escrow agent undertakes to ensure the safety of this property and transfer to its beneficiary in the event of the grounds specified in the agreement (Civil Code of the Russian Federation, 1994: article 926.1, clause 1). The EA is a tripartite agreement: it is concluded between the depositor, the beneficiary, and the escrow agent (Civil Code of the Russian Federation, 1994: article 926.1, clause 1, paragraph 2).

A basic scheme of the relationship of its parties on regulating the execution order with the help of an escrow agent of a unilateral obligation that arose between the depositor-debtor and the beneficiary-creditor of the debtor found expression in the EA's design. However, civil turnover is more characterized by agreements that give rise to bilateral obligations, for the implementation of which the EA's design can also be applied (Civil Code of the Russian Federation, 1994: article 926.1, clause 6). In this case, each of the counterparties of the bilateral agreement simultaneously performs the functions of both the depositor (in terms of the obligation to transfer property to the other party) and the beneficiary (in terms of the requirements for the counterparty under the property transfer agreement, for example, under the purchase and sale agreement) (Vitryansky, 2018).

The structure of contractual relations between the escrow agent, the depositor, and the beneficiary can be represented by at least two agreements: (1) the main agreement between the creditor and the debtor for the transfer of property (for example, the purchase and sale agreement) and (2) the EA between the escrow agent, the depositor (debtor of the primary obligation) and the beneficiary (creditor of the primary obligation). In the framework of the emerging escrow-relationship, the depositor (debtor of the main obligation) to fulfill his obligation under the purchase and sale agreement - providing property to the beneficiary (creditor in the main obligation) transfers this property not to their counter-party under the purchase and sale agreement, but the escrow agent - counter-party for the EA. That is, the debtor carries out its execution under the sales agreement through an escrow agent.

Upon the occurrence of the circumstances provided for by the EA, the beneficiary has the right to require the escrow agent to transfer to the beneficiary the property provided by the depositor. The escrow agent acts in the interests of the creditor and the debtor, that is, as a "trustee" who 
Liudmila Yu. Vasilevskaya y Marina A. Rozhkova

Provision of Escrow Services at the Absence of an Agreement: the Assessment for Compliance

fulfills his obligations under the EA. At the same time, remaining a neutral party to both the creditor and the debtor, the escrow agent "guarantees" the fulfillment of the obligations of both parties under the purchase and sale agreement. Thus, an escrow agent is an independent third party, an intermediary that provides its services to the parties to the EA, with the help of which the "guarantee" implementation mechanism is implemented under the main agreement.

By clause 3 of Article 926.1 of the RF CC, the object of deposit may be as follows: movable things (including cash, documentary securities, and documents), as well as property rights (cashless funds, uncertified securities) (Civil Code of the Russian Federation, 1994: article 926.1, clause 3). Particularly, Russian law regulates the procedure for depositing noncash funds. If the escrow agent is not a bank, cashless funds are deposited in their nominal account. Moreover, according to clause 3 of Article 926.6 of the RF CC, the beneficiary of the nominal account opened by the escrow agent is the depositor before the date set by the EA for transferring the property to the beneficiary, and after that date - the beneficiary of this nominal account is the beneficiary of the EA (Civil Code of the Russian Federation, 1994: article 926.6, clause 3).

\section{Nominal Account Agreement (Hereinafter Referred to as the NAA)}

In developing what has been said, attention should be paid to the following circumstance. If the escrow agent is not a bank, then to deposit non-cash funds in its nominal account of its counter-party (depositor) under the EA, the escrow agent must conclude the NAA with the bank (Vasilevskaya, 2017) (Civil Code of the Russian Federation, 1994: articles 860.1-860.6). Moreover, the NAA, as indicated in clause 1 of Article 860.2 of the RF CC (Civil Code of the Russian Federation, 1994: article 860.2, clause 1), shall be done in writing by drawing up one document signed by the parties (Civil Code of the Russian Federation, 1994: article 434, clause 2), with the obligatory indication of the date of its conclusion.

A nominal account is opened to the account holder - an escrow agent (bank counter-party under the NAA) to carry out operations with funds the rights to which belong to one or several beneficiaries - counter-parties of an escrow agent for the EA (Civil Code of the Russian Federation, 1994: article 860.1). It is obvious that initially the beneficiary of the nominal account opened by the bank with the escrow agent is the depositor who transferred non-cash funds to the escrow agent through the EA. Upon the occurrence of the grounds provided for by the EA for transferring the property to the beneficiary, the status of the beneficiary in the nominal account passes from the depositor to the beneficiary in the EA. 
Under clause 2 of Article 860.2 of the RF CC, the NAA can be concluded both with and without the participation of the beneficiary (Civil Code of the Russian Federation, 1994: article 860.2, clause 2). The NAA without the participation of the beneficiary is bilateral (concluded between the bank and the account holder - escrow agent) - its legal structure was developed by the Russian legislator according to the model of the agreement in favor of a third party (beneficiary). The NAA with the participation of the beneficiary, like the EA, is multilateral.

For this study, of special attention is that, according to Russian law, the conditional deposit of non-cash funds in cases where the escrow agent is not a bank is allowed subject to the conclusion of the NAA with the bank. The consequence of this is the complication of the structure of contractual relations between the escrow agent, the depositor and the beneficiary: in this case, the design of the EA is additionally burdened by the conclusion of the NAA between the escrow agent and the bank. In this case, the status of the beneficiary in the nominal account until the date of the grounds for transferring the property to the beneficiary is with the depositor (according to the EA), and after the specified date - by the beneficiary (according to the EA).

\section{Escrow Account Agreement (Hereinafter Referred to as the EAA)}

In addition to the above, Russian law also provides for a different model of the relationship of the escrow agent with its counter-parties to the EA (depositor and beneficiary). The authors are talking about the design of the EAA (Civil Code of the Russian Federation, 1994: articles 860.7-860.10), which should be distinguished from the design of the EA considered above (including the "burdened" NAA). It is important to note that the general provisions on the bank account and the EA (chapter 47.1) apply to the parties to relations on the EAA unless otherwise provided by articles 860.7-860.10 of the RF CC (Civil Code of the Russian Federation, 1994: articles 860.7-860.10) or does not follow from the essence of the relations of the parties (Civil Code of the Russian Federation, 1994: article 860.7, clause 4). In other words, in the disassembled model of the relationship between the escrow agent, the depositor and the beneficiary, instead of the NAA, the EAA is concluded, and not the nominal account, but the special escrow account is opened for the account holder.

According to the EAA, the bank, which is an escrow agent, opens a special escrow account to record and block money received from the account holder (depositor) to transfer it to another person in case of grounds stipulated by the agreement between the bank, depositor, and beneficiary (Civil 
Liudmila Yu. Vasilevskaya y Marina A. Rozhkova

Provision of Escrow Services at the Absence of an Agreement: the Assessment for Compliance 118 with the Russian Law

Code of the Russian Federation, 1994: article 860.7, clause 1). Thus, the functions of the escrow agent in these contractual structures are performed by the bank, the escrow agent (according to the EA) becomes the account holder (depositor), and the beneficiary (according to the EA) remains the beneficiary in the EAA.

The Russian legislator initially provided for a rather complex system of relations between the escrow agent, the depositor and the beneficiary. In the authors' opinion, a literal reading of the norm of clause 1 of Article 860.7 of the RF CC (Civil Code of the Russian Federation, 1994: article 860.7, clause 1) makes it possible to consider the EAA as a kind of the EA, the differences between which are due primarily to the specifics of the subject composition and the object of deposit. According to the EA, any physical and legal person, including banks, can act as an escrow agent, and, as already noted, the object of the deposit is movable things and property rights such as cashless funds and non-documentary securities. According to the EAA, only banks are the escrow agent, and only cash is the subject of accounting and blocking on a special escrow account (Civil Code of the Russian Federation, 1994: article 860.7, clause 1).

\section{Problems of the Legal Nature of the EAA}

The Russian doctrine has various opinions on the question of whether it is possible to consider the EAA as a kind of the EA. However, literature more often contains opinions that the EAA and the EA are interrelated agreements - entering the EA should be preceded by entering the EAA. For example, V.D. Rudakova writes that "relations on an escrow account are usually executed in two agreements: 1) escrow account agreement, which is the basis for opening an account and is concluded between the bank and the depositor; 2) an agreement on the conditional deposit of funds concluded between the bank, the depositor, and the beneficiary, which stipulates the conditions and grounds for the transfer of funds by the bank to the beneficiary" (Slesarev, 2016). N.G. Solomina expresses a similar view: "Given the logic of the legislator, if the bank acts as an escrow agent, then, in addition to the escrow agreement, it is assumed that there is an escrow account agreement, which is concluded in fulfillment of the first" (Solomina, 2019).

It is difficult to support such an interpretation of the pattern of the emergence of relations between the exclusion agent, the depositor and the beneficiary: the conclusion of the EAA deprives the legal conclusion of the EA of legal sense, since in this case either the first agreement acquires the properties of a preliminary agreement, or the second agreement loses its legal purpose. L.G. Efimova expresses another opinion, indicating the 
artificial nature of the structure, fixed by Article 860.7 of the RF CC (Civil Code of the Russian Federation, 1994: article 860.7): “...the depositor is practically deprived of the right to perform any operations on this account. Such an account is managed by the bank itself - an escrow agent" (Efimova, 2018).

In the development of the previously mentioned, it should be noted that the issue of the admissibility of the recognition of the beneficiary by the EAA side has not received permission either. Due to the lack of relevant norms in the RF CC, the position of the legislator on this issue is not clear, because of which various positions are expressed by Russian legal scholars. For example, according to V.D. Rudakova, if the EAA is concluded between the bank and the depositor (Slesarev, 2016), then it should be consensual, bilaterally binding (synallagmatic). Nevertheless, this position raises many counter-questions. If the EAA is concluded without the participation of the beneficiary, then on what basis does the right of the beneficiary arise to require the bank to provide information constituting bank secrecy, which is directly provided for in Article 860.9 of the RF CC (Civil Code of the Russian Federation, 1994: article 860.9)? Why does clause 1 of Article 860.8 of the RF CC (Civil Code of the Russian Federation, 1994: article 860.8, clause 1) (the norm of which is dispositive) provide for a ban on the disposal of funds for the beneficiary? It is not yet possible to get unambiguous answers to these questions.

A large number of unresolved issues and the inability to give clear answers to them are explained by the lack of a clear idea of the need to determine the fulfillment of the main agreement through the mechanism for concluding and executing two agreements - the EAA and the EA and obvious contradictions in the logic of draft law developers. In the authors' opinion, the structure of the relationship between the parties should be presented as follows: (1) the main agreement between the creditor and the debtor for the transfer of property (for example, a purchase and sale agreement) and (2) the EAA is concluded between the escrow agent (bank), the depositor (debtor for the primary obligation) and the beneficiary (creditor for the primary obligation).

\section{Analysis: Legal Assessment of the Contractual Structures Proposed by the Online Classified}

According to clause 1 of Article 174.2 of the Tax Code of the Russian Federation (Tax Code of the Russian Federation, 1998: article 174.2, clause 1), electronic services are considered to be provided through the Internet, "to provide technical, organizational, information and other opportunities carried out using information technologies and systems, to establish 
Liudmila Yu. Vasilevskaya y Marina A. Rozhkova

Provision of Escrow Services at the Absence of an Agreement: the Assessment for Compliance

contacts and conclude transactions between sellers and buyers (including the provision of a trading platform operating on the Internet in real-time, on which potential buyers offer their price through an automated procedure and the parties are notified of the sale by sending automatically generated messages)". Therefore, this kind of service provided by the online classified, which is essentially an intermediary facilitating the transaction between the seller and the buyer, can rightfully be attributed to the electronic services.

For this work, first, it is necessary to understand what becomes the legal basis for the provision of the Avito Delivery range of services (hereinafter referred to as the Range of Services) (Avito Delivery, in: https://www.avito.ru/ dostavka, n.d.). Moreover, here it is impossible not to pay attention to the fact that the buyer, aimed at obtaining the Range of Services, performs several sequential actions, some of which are carried out as part of an automated procedure.

1. The initial step is the confirmation by the buyer of his decision to purchase a specific product from the seller using the Range of Services, which is done by clicking the "Buy with Delivery" button. After that, the Internet platform system offers the buyer to choose a point of delivery of the purchased goods convenient for him, and it turns out that the delivery of goods is carried out by third parties - third-party delivery services that have points of delivery of online orders. Having chosen a suitable point of delivery, the buyer gets to the checkout page.

2. On the checkout page, the total order value is indicated, which consists of the price of the goods and the cost of its delivery directly to the point of delivery. The buyer is requested to indicate their name, phone number, and email address. In this case, the user is not explicitly required to confirm the acceptance of any contractual terms. At the same time, the page contains the inscription "By clicking "Go to payment" you accept the offer and confirm the accuracy of your data", where the word "offer" is a hyperlink leading to the page "Delivery and secure payment at Avito" (hereinafter referred to as the Terms of delivery and payment).

Turning to the contents of clause 1 of the Delivery and Payment Terms, one can see that "delivery at Avito" means a range of services that allow the seller and the buyer to use when fulfilling their obligations under the transaction: (1) payment service, (2) delivery services, (3) other services that are provided by KEX eCommerce (a subsidiary of Avito Holding AB, hereinafter referred to as the Company), as well as by other persons. At the same time, the involvement of third parties for the execution of the agreement is confirmed: delivery services - to provide services for the delivery of purchased goods; Bank (QIWI Bank) - to provide a payment service.

Another circumstance is noteworthy. The Avito Delivery FAQ page specifically emphasizes that a delivery charge is charged to the buyer, but 
no additional fees are charged. At the same time, clause 2.1.1 of the Terms of delivery and payment mentions a very wide range of services provided by the Company: "Services to provide the buyer with functionality that enables the payment of goods by bank transfer using the Payment service, to exchange information between the seller, the bank, the buyer and the delivery service to conclude and execute a Transaction using delivery at Avito", the payment of which is entrusted to the buyer.

3. Pressing the "Go to payment" button takes the buyer to the payment page, where (s)he must enter the bank card number and other necessary payment details, which results in the reservation of the mentioned amount of money on the buyer's card by the system. Noteworthy is the indication at the bottom of the page that the service is provided by Tinkoff Bank. Although clause 1 of the Terms of delivery and payment, as mentioned above, names another bank as the bank providing the payment service - QIWI Bank.

4. After receipt of the purchased goods at the point of delivery, if the buyer picks it up, the reserved amount of money is transferred to the seller's account. If the buyer refused the goods arrived, then the money is saved in their bank account. That is, within the framework of the considered Range of Services, a conditional deposit of funds of the buyer occurs. Moreover, in clause 2.4 of the Terms of Delivery and Payment (Avito Terms of Delivery and Secure Payment, n.d.: clause 2.4), the Company states that it is not "a party to the Transaction, the organizer of the Transaction, the buyer, seller, intermediary, agent or representative of any user and/or another interested person concerning the proposed/concluded between users of the Transaction. All transactions between users are concluded and executed without direct or indirect participation of the Company".

The structure of the considered relationship between the buyer, seller, online classified, delivery service and the bank is predetermined by several agreements. Firstly, the purchase and sale agreement (the main agreement), for a monetary obligation from which the buyer is the debtor, and the seller is the creditor. Secondly, the carriage of goods agreement, the execution of which is carried out for the debtor (online classified) by third parties delivery services. Thirdly, the use of a payment service agreement concluded by the buyer with the bank, according to which the bank renders the buyer the services of transferring and reserving funds, (the reservation of the buyer's funds by the bank is mentioned, in particular, in clause 3.5 of the Terms of Delivery and Payment and Appendix No. 2 (Avito Terms of Delivery and Secure Payment, n.d.: clause 3.5, appendix 2)).

The authors believe that there is a conditional escrow of property in the framework of the considered relations, but the fact of concluding an agreement creating an appropriate legal basis for such an escrow is not observed. As mentioned above, the provision of a service of depositing noncash funds allows two scenarios. The first scenario is the entering the EA 
Liudmila Yu. Vasilevskaya y Marina A. Rozhkova

Provision of Escrow Services at the Absence of an Agreement: the Assessment for Compliance

(here: between an online classified as an escrow agent, seller and buyer) simultaneously with the conclusion of a NAA (which can be both bilateral - between the bank and the escrow agent, and multilateral - the bank, the escrow agent and the beneficiary). The second scenario is entering the EAA, in which the bank becomes the escrow agent, and the online classified is the account holder (depositor).

From the information provided on the classified website, it follows that the Company (online classified) offers registered users of its website the Range of Services, including the conditional deposit of funds of the buyer, which is designed to ensure the proper execution of the main purchase and sale agreement concluded by the seller and the buyer. However, familiarization with the procedure for obtaining the Range of Services and the Terms of Delivery and Payment provides all grounds for concluding that there is a clear departure from the contractual relationship scheme provided for by the RF CC with the participation of an escrow agent. In other words, the complex relationship system built by online classified with sellers, buyers, a delivery service, a bank and providing for the reservation of the buyer's money does not include escrow agreements. Under these conditions, and taking into account the mentioned non-obviousness of the bank providing such services, the provided Range of Services cannot be considered as meeting the requirements of the Russian law.

\section{Conclusion}

The study concludes that the problem of providing a variety of electronic services with online classifieds is undeservedly deprived of the attention of Russian civil lawyers. A complex of theoretical and practical issues remains unresolved, related to the escrow service quite widespread in recent times, which is provided by online classifieds to its users when delivering goods. The authors have identified the problems, gaps in legislative regulation and the made proposals will serve as the basis for continuing the scientific discussion on the issues of escrow services in the digital environment.

\section{Bibliographic References ${ }^{3}$}

AVITO DELIVERY. n.d. Available online. In: https://www.avito.ru/dostavka. Date of consultation: 21/01/2020.

3 Although the regulations for authors of this journal require the full names of the authors to be added to this list of references, unfortunately in some cases the sources of origin only consider the initial of the name. 
AVITO TERMS OF DELIVERY AND SECURE PAYMENT. (n.d.). Date Views 21.01.2020.Available online.In:https://support.avito.ru/articles/688? $\mathrm{ga}=2.148998974 .942453385 .1586263237-484388421.1586263237$. Date of consultation:21/01/2020.

CIVIL CODE OF THE RUSSIAN FEDERATION. 1994. Available online. In: http://www.consultant.ru/cons/cgi/online.cgi?req $=$ doc $\&$ base $=\mathrm{LAW} \& \mathrm{n}=340325 \& \mathrm{fld}=134 \& \mathrm{dst}=1000000001,0$ \&rnd $=0.1469650009780934 \# 08274525429409993 . \quad$ Date of consultation:21/01/2020.

EFIMOVA, L.G. 2018. Bank Deposit and Bank Account Agreements: Monograph. Prospect. Moscow, Russia.

FEDERAL LAW OF JULY 26, 2017 NO. 212. n.d. "On Amendments to Parts One and Two of the Civil Code of the Russian Federation and Certain Legislative Acts of the Russian Federation”. Available online. In: https://normativ.kontur.ru/document?moduleId=1\&document $\mathrm{Id}=297777$. Date of consultation:21/01/2020.

ROZHKOVA, M.A. 2019. Databases and services of online classifieds: using the database and using information. Journal of the Court of Intellectual Property Rights, Vol. 26: pp. 25-32.

SLESAREV, V.L. 2016. Civil Law: A Textbook for Bachelor Students. Prospect. Moscow, Russia.

SOLOMINA, N.G. 2019. On the issue of the escrow agreement. Law and Economics, 10. Moscow, Russia.

TAX CODE OF THE RUSSIAN FEDERATION. 1998. Available online. In: http://www.consultant.ru/document/cons_doc_LAW_19671/. Date of consultation:21/01/2020.

VASILEVSKAYA, L.YU. 2016. Escrow account agreement: problems of legal qualification. Russian Law Journal, Nu. 2: pp. 37-49.

VASILEVSKAYA, L.YU. 2017. Nominal account and escrow account agreements: general and special in legal regulation. Civil Law, Nu. 3, pp. 3-5.

VITRYANSKY, V.V. 2018. Reform of Russian Civil Law: Interim Results. Statute. Moscow, Russia. 

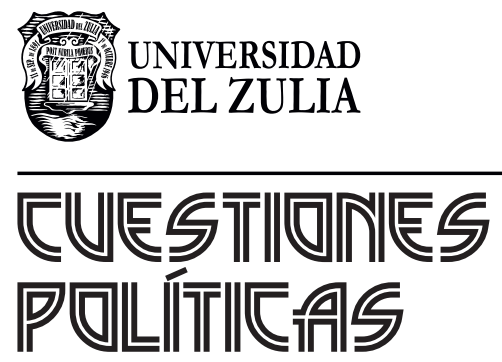

Vol. $37 \mathrm{~N}^{\circ} 64$

Esta revista fue editada en formato digital y publicada en junio de 2020, por el Fondo Editorial Serbiluz, Universidad del Zulia. Maracaibo-Venezuela 